\title{
Using Electronic Design Automation and Guided Inquiry Learning Model in Higher Engineering Education
}

\author{
Moch Rifai ${ }^{1, *}$, Siti Masitoh ${ }^{2}$, Bachtiar S. Bachri', Wawan H. Setyawan ${ }^{3}$, Nurdyansyah ${ }^{4}$, \\ Hesty Puspitasari ${ }^{5}$ \\ ${ }^{1}$ Department of Air Navigation Engineering, Politeknik Penerbangan Surabaya, Indonesia \\ ${ }^{2}$ Department of Education Technology, Universitas Negeri Surabaya, Indonesia \\ ${ }^{3}$ Department of English Education, Universitas Islam Kadiri, Indonesia \\ ${ }^{4}$ Department of Elementary School Teacher Education, Universitas Muhammadiyah Sidoarjo, Indonesia \\ ${ }^{5}$ Department of English Education, Universitas Islam Balitar, Indonesia
}

Received March 22, 2020; Revised May 26, 2020; Accepted June 24, 2020

Copyright (C2020 by authors, all rights reserved. Authors agree that this article remains permanently open access under the terms of the Creative Commons Attribution License 4.0 International License

\begin{abstract}
Electronic design automation software is a part of software learning. This study uses digital electronic circuit design software as learning media, namely, Electronic Design Automation (EDA), in the form of simulations and a guided inquiry learning model in higher engineering education. The device is a type of multimedia, because it involves graphics, animation, and text as external data. The software facilitates the learning process of cadets using the guided inquiry learning model. Given its accessibility, mobile learning has its own advantages. This study uses quantitative data with a type of quasi-experimental research. The sample consists of 100 cadets in the engineering study program. Results show that the model can improve the learning process of cadets in the air digital engineering program subject, in which the implementation of the model has been integrated into a special theme from the test scores and results of cadets. An effect is observed on the use of the EDA and guided inquiry model to the learning outcome and motivation of cadets in engineering education. The researchers concluded that the implementation of EDA and the guided inquiry model are effective. In addition, it provides benefits for practitioners and educators in improving the learning outcomes and motivation of cadets in engineering education.
\end{abstract}

Keywords Electronic Design Automation Software, Guided Inquiry Learning Model, Digital Engineering

\section{Introduction}

Surabaya Aviation Polytechnic is an organization of vocational education providers under the Ministry of Transportation [1], [2]. Their aim is to form and produce graduates equipped with knowledge, skills, and expertise in the air transportation subsector [3], [4]. However, group learning limits each individual cadet from exploring to achieve a high level of expected technical mastery [5], [6]. The previous studied have found a lack of active involvement of cadets in practical activities [7], [8].

Recent developments in Web 4.0 technology have demonstrated that learning in engineering education can be supported by technology that is accessible to cadets [9] wherever they are and by location-based learning in assisting active, practical activities [10], [11]. Therefore, the use of the latest learning media through technology can help cadets become increasingly active in practical activities. A new type of technology, namely, Electronic Design Automation (EDA), has become popular because of the need to overcome the complexity and scalability in design with more than one billion transistors [12], [13].

EDA is an engineering science that combines software and hardware for integrated circuit and system design based on abstraction, design methodology, software implementation of sophisticated algorithms for verification, and synthesis. Computer scientists, mathematicians, and physicists recommend the use of EDA [12]. At the same time, EDA is becoming a complex sensor network covering various fields of technology, thus creating new goals for digital engineering. EDA can be designed as digital electronic circuits in the form of simulations in engineering education learning [14], [15]. It is considered multimedia because it involves graphics, animation, and text as external data [16]-[18]. Previous 
studies have demonstrated that information and communications technology influences the development of learning media, especially media in the form of design software [19]-[22].

The use of EDA in learning can be optimized by applying the guided inquiry learning model. Guided inquiry learning model capabilities can be trained through several stages, namely, pre-teaching, during teaching, and post-teaching [23]-[25]. In the delivery of the learning of model material, the countdown operates without planning and design [26], [27]. The guided inquiry learning model can accommodate the learning outcome of cadets [28]. The learning process of this model includes a series of learning activities where analytical thinking in searching for and finding answers to a problem is developed among cadets by using the cadets as subject in the activities [29], [30]. Thus, the purpose of this study is to identify whether the use of EDA learning media in the application of guided inquiry learning models influences the learning outcome and motivation of cadets.

\section{Literature Review}

\subsection{Inquiry Learning Model}

The implementation of the basic concept of the guided inquiry learning model, the basic concept of learning outcomes, and scientific knowledge provide a wide scope for cadets to find a concept in an article, journal, scientific study, and other literacy studies [31]. The search is integrated with general scientific knowledge (science) and Islamic values [32], [33] so that cadets in the corresponding stage in the inquiry model can comprehensively find solutions to the problem.

Table 1 shows the syntax of the guided inquiry learning model. The guided inquiry learning in this study has three stages, namely, pre-teaching, during teaching, and post-teaching. In the pre-teaching stage, cadets are given a stimulus to form initial knowledge in this form of learning. During the teaching stage, cadets go through four phases of guided inquiry learning, namely, orientation, organization, introductions to concepts, and publication. In the post-teaching stage, the cadets undergo strengthening and reflection.

Table 1. Syntax guided inquiry model

\begin{tabular}{|c|c|c|}
\hline Syntax & Learning Strategy & Time Allocation \\
\hline $\begin{array}{c}\text { Stage } 1 \\
\text { Pre-teaching }\end{array}$ & $\begin{array}{l}\text { 1. The teacher provides an explanation of the learning activities that will be carried out today. } \\
\text { 2. The teacher gives apperception about the material that will be studied today. } \\
\text { 3. The teacher invites cadets to express their initial opinion about the subject matter. } \\
\text { This discussion allows the teacher to determine the initial knowledge of the cadets. } \\
\text { 4. The teacher explains the objective of learning this introduction material. }\end{array}$ & 15 minutes \\
\hline $\begin{array}{c}\text { Stage } 2 \\
\text { During } \\
\text { Teaching }\end{array}$ & $\begin{array}{l}\text { Phase } 1 \text { (Orientation) } \\
\text { 1. The teacher gives the procedures for discussion based on the CIRC concept. } \\
\text { 2. The teacher gives material or discourse to cadets to be discussed in groups. } \\
\text { 3. The teacher gives new introductory material to cadets. } \\
\text { Phase } 2 \text { (Organization) } \\
\text { 1. Cadets are grouped based on the number of cadets in one class. One group can have 4-5 people. } \\
\text { 2. The teacher gives material or discourse to cadets to be discussed in groups. } \\
\text { Phase } 3 \text { (Introduction to Concepts) } \\
\text { 1. The teacher gives new introductory material to cadets. } \\
\text { 2. The teacher gives assignments to cadets to find examples of introductory texts from various } \\
\text { sources, which will be discussed in the second meeting. } \\
\text { 3. The teacher collects examples of introduction text in clippings. } \\
\text { 4. The cadets are asked, among other things, about the differences between the various simple } \\
\text { introductory texts that are written in English and the differences in texts in English from those } \\
\text { in Indonesian especially about social functions, text structure, and linguistic elements. } \\
\text { 5. The teacher asks about the main ideas, detailed information, and certain information from a } \\
\text { simple text introduction about activities/events. } \\
\text { Phase } 4 \text { (Publication) } \\
\text { 1. The teacher makes a report of the results of the discussion about the introduction material about } \\
\text { social functions and text structure and language. } \\
\text { 2. The teacher collects the assignments via email. }\end{array}$ & 20 minutes \\
\hline $\begin{array}{c}\text { Stage } 3 \\
\text { Post-teaching }\end{array}$ & $\begin{array}{l}\text { Phase } 5 \text { (Strengthening and Reflection) } \\
\text { The teacher and cadets together make conclusions about the characteristics of the introduction text. }\end{array}$ & 5 minutes \\
\hline
\end{tabular}




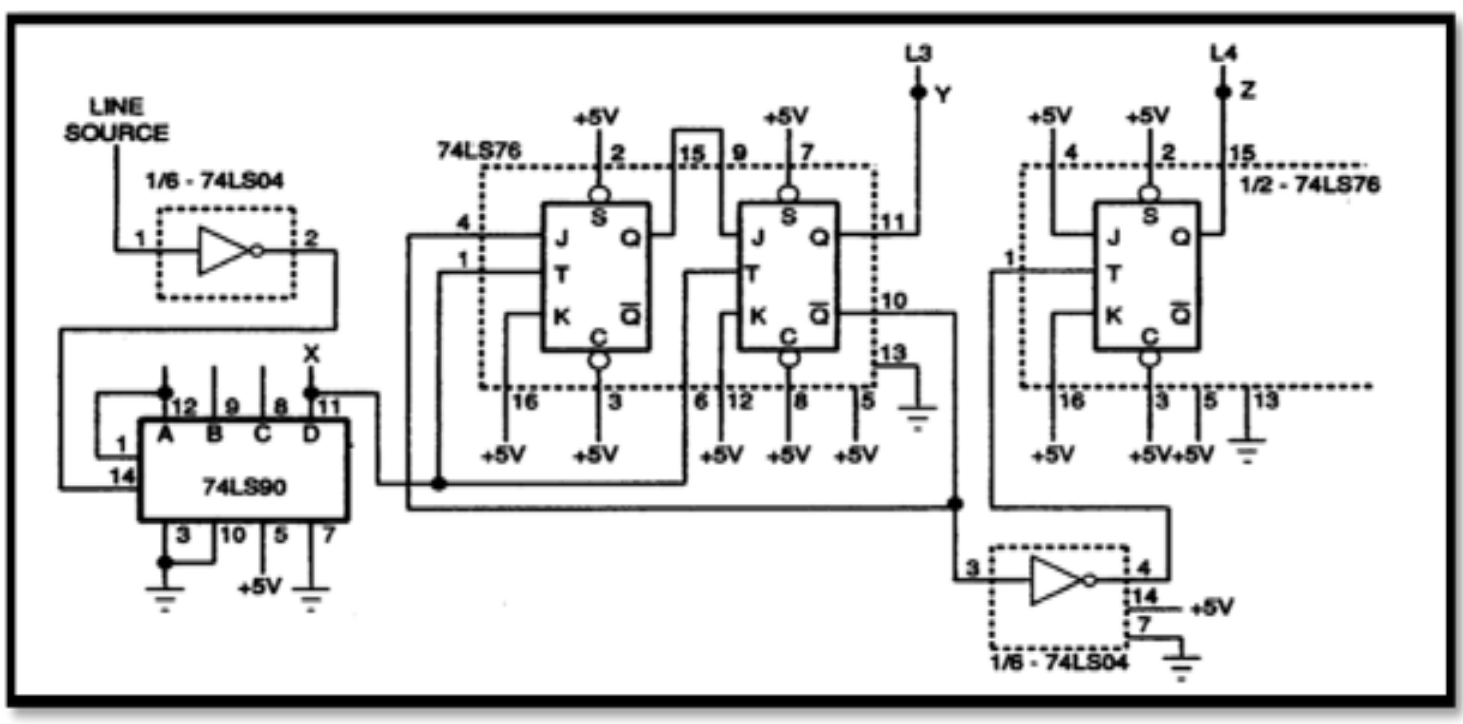

Figure 1. The circuit functions to produce the number of pulses

\subsection{Circuit Functions in EDA}

With the development of the electronics industry and the emergence of large- and very large-scale integrated circuits, circuit design and analysis are becoming increasingly complex, and the requirements for circuit design reliability and design cycle are increasingly high [12]. Design and analysis of artificial circuits cannot meet the general requirements. Therefore, the assistance of computer simulations and circuit analysis has become very important. However, with the rapid development of the computer industry, characteristics, such as high speed, large capacity, high precision, and easy operation make computers excellent technical conditions for circuit simulation and thus promote the development of circuit simulation technology. To solve the design problems and development of large-scale integrated circuits, EDA technology has emerged. EDA technology based on Computer Aided Design (CAD) has been gradually developed from the main logic circuits that can be programmed for design and development. Software tools are used to complete the input of circuits, logic synthesis, process mapping, cable layout, and bitstream download throughout the comprehensive technological process.

Figure 1 shows the circuit of functions to produce the number of pulses that are needed to set the binary data I / $p$ on the counter and drive I / p data is the o / p state with member binary 0 on pin 11 (Load). The counter counts (Down counter) from o $/ \mathrm{p}$ state $=0000$, and pin 13 (Borrow) returns binary 0 . Thus, $\mathrm{o} / \mathrm{p}$ Gate $1=0, \mathrm{o} / \mathrm{p}$ Gate $2=0, \mathrm{o} /$ $\mathrm{p}$ Gate $3=1$, and $\mathrm{o} / \mathrm{p}$ Gate $4=0$. Then, the counter stops Stepping. o / p, which is observed at L1 (pin 4), will only produce as many pulses as binary data $\mathrm{i} / \mathrm{p}$, which is given [34].

\section{Methods}

\subsection{Research Design}

This study used the quantitative data with a type of quasi-experimental research in which numeric data were analyzed to identify the influence of EDA learning media and guided inquiry learning models. Quasi-experimental research is a model that provides treatment to all subjects [35]. In this research, both the experimental and control groups got the same material, which was to design a circuit to make semiconductor testers for four weeks. The sub-material for each week adjusts the category of semiconductor testers consisting of digital, memory, analogue, and mixed-signal.

This research underwent several steps, namely, the provision of the pre-test, action learning, value clarification, concept mapping, and post-test. The hypothesis tested in this study was carried out at an alpha level of 0.05 using paired sample t-tests to process the data collected in this study because of a higher power that allowed it to filter out initial differences in covariates.

\subsection{Sampling and Instrument}

The research subjects were second-semester cadets in the Air Navigation Engineering Study Program (TNU) and the Airport Electrical Engineering Study Program (TLB). The purposive sampling technique determined the cadets of Study Program TNU IX A and TLB XIA, totaling 50 cadets, as the experimental group (EDA-assisted guided inquiry learning model) and the cadets of Study Program TNU IX B and TLB XIB, totaling 50 cadets, as the control group (guided inquiry learning model). The data on learning outcomes were collected using learning outcome tests in the form of descriptions. 
The research instruments consist of tests of learning outcomes and a questionnaire. They are given before and after the application of learning in the experimental and control groups. The learning achievement test contained 10 problem descriptions, including how cadets design a circuit to make semiconductor testers. The questionnaire contained 25 questions on cadet motivation, which included 5 questions each about perseverance in learning, tenacity in facing difficulties, interest and sharpness in learning, perception of achievement in learning, and independence in learning.

\subsection{Data Analysis Techniques}

The analysis techniques used in this study are inferential statistics and descriptive statistics. Inferential statistics are done by testing paired sample t-tests, while descriptive statistics are done by determining the comparison of the mean, median, and mode of learning outcome data and cadets motivation.

This study used paired-sample t-test analysis, which is a procedure used to compare the average of two variables in one group. It tested one sample that received a treatment that was then compared on average from the sample between before and after treatment. The collected data was processed statistically by using t-test with a significance level of 0.05 .

Expert assessment mechanism was used, which included the following. 1) Content Experts: At this stage, data were obtained from consultations with experts. One person was an expert in mathematics education in schools. The data were obtained through structured interviews, the results of the consultation, and the question form. 2) Expert Design Assessment is performed by an expert in design. The assessment rests on several criteria, including an attractive design, shape and size of the corresponding font, color pictures, color, and the alignment of the image. 3) Linguist Assessment conducted by an expert examines the statutes, spelling, effectiveness of the sentence, punctuation, vocabulary used, and communicative language.

\section{Results and Discussion}

\subsection{EDA in Guided Inquiry Learning}

In this study, the activity of cadets in the experimental group during the design of circuits to make semiconductor testers using EDA in Guided Inquiry Learning adjusts its submitters, namely digital, memory, analogue, and mixed-signal. Researchers call these activities as digital activities, memory activities, analogue activities, and mixed-signal activities. Digital activity is the activity of cadets in optimizing digital circuits and systems with a large number of high-speed digital Input / Output pins and a limited number of analog capabilities. Meanwhile, memory activity is the activity of cadets in optimizing testing of memory devices. Analogue activity is the activity of cadets determining analog circuits with high-performance input / output current and high-voltage analog pins, with high-performance data acquisition (analog to digital conversion) and signal analysis capabilities. Mixed-signal activity is a cadets activity in testing the digital and analog Input / Output levels required in the circuit.

Figure 2 shows the first activity namely digital. Cadets design circuits in digital systems so as to form an automated electronic product. In the process of making EDA, cadets need a logic probe to provide an output in the flow of electricity. In guided inquiry learning, cadets are invited to make a logic probe and logic state using EDA. This guided inquiry learning helps cadets step by step according to the stages of guided inquiry learning. Cadets solve problems in making circuits using EDA so that cadets can formulate hypotheses and test these hypotheses using EDA. 


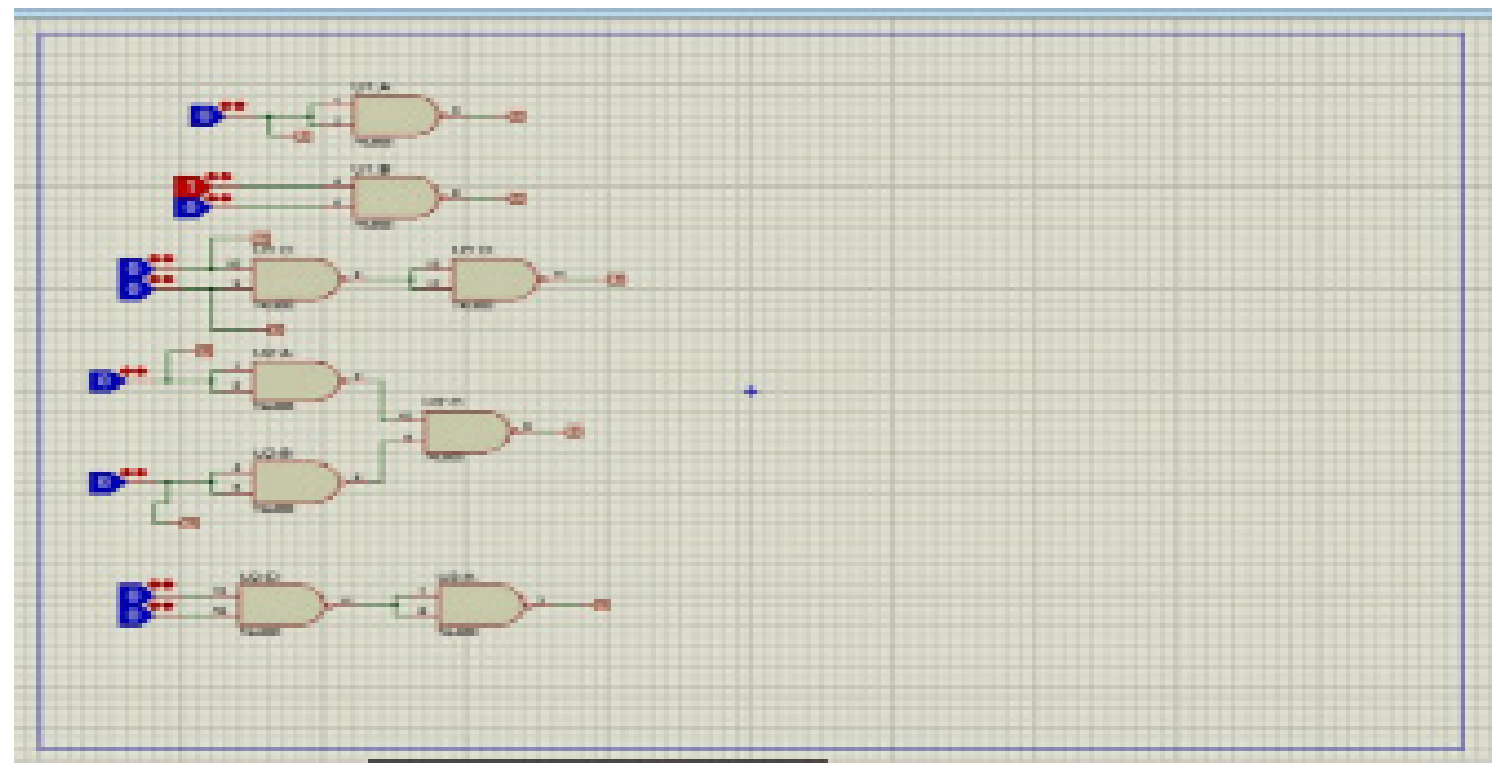

Figure 2. Logic probe

After carrying out learning activities in the experimental and control groups, the researcher gave a post-test to all cadets to find out the cadets learning outcomes. Pretest and post-test were obtained through test of learning outcomes distributed to 50 cadets. The test was in the form of 10 question items that contain about how students draw a circuit design to make semiconductor testers.

Table 2. Descriptive analysis of the experiment and the control class

\begin{tabular}{|c|c|c|}
\hline & Experiment Class & Control Class \\
\hline Mean & 80.60 & 77.40 \\
\hline Median & 74.00 & 68.00 \\
\hline Modus & 80.00 & 74.00 \\
\hline Standart Deviasi & 38 & 40 \\
\hline Varians & 10,16 & 11,02 \\
\hline
\end{tabular}

Table 2 shows the results of the descriptive analysis of cadets learning outcomes. The average learning outcomes of circuit design material for the experimental class is 80.60 , which if converted to a rating scale of minimum learning values, the scores are categorized as good [36]. Meanwhile, in the control group learning circuit design, an average value of 77.40 was obtained and if it is converted to a rating scale of learning minimum values, the value is quite good [36].

The results of the feasibility tests of various t-tests on the pre-test and post-test on experiment groups can be seen in Figure 3. The average rating can determine the difference between the learning outcome of the pre-test and post-test results, i.e., the pre-test results show an average value of 57.44 , and the post-test results show an average value of 80.60. It was found that students had high learning outcomes at pretest almost reaching 80. However, their learning outcomes at post-test increased and were the highest compared to other cadets learning outcomes. This is because some of these students have good cognitive abilities before the implementation of the guided inquiry learning model using the EDA application.

Table 3. T-test analysis of hypothesis

\begin{tabular}{|c|c|c|c|}
\hline T count & T-table & df & Influence \\
\hline 2.819 & 1.68 & 38 & 0.665 \\
\hline
\end{tabular}

Table 3 presents the relationship between the test results and the learning outcome model. The value of $t$ observation or $\mathrm{t}$ count is 2.819 , and at the level of $0,05(\mathrm{df}=38)$, the $\mathrm{t}$ table value is 1.68 . The value of the $p$-t test statistic value of 0.00 is $(<0.05)$. Thus, the Ho is rejected, and the $\mathrm{Ha}$ is received. The conclusion demonstrates a significant influence on the average value of the pre-test and post-test. A test on the effectiveness of this test is conducted to find out the level of effectiveness of the models used. Thus, it can be interpreted that there was a significant difference between student learning outcomes that were applied in guided inquiry learning models using the EDA application and students who took part in learning with guided inquiry learning models only. 


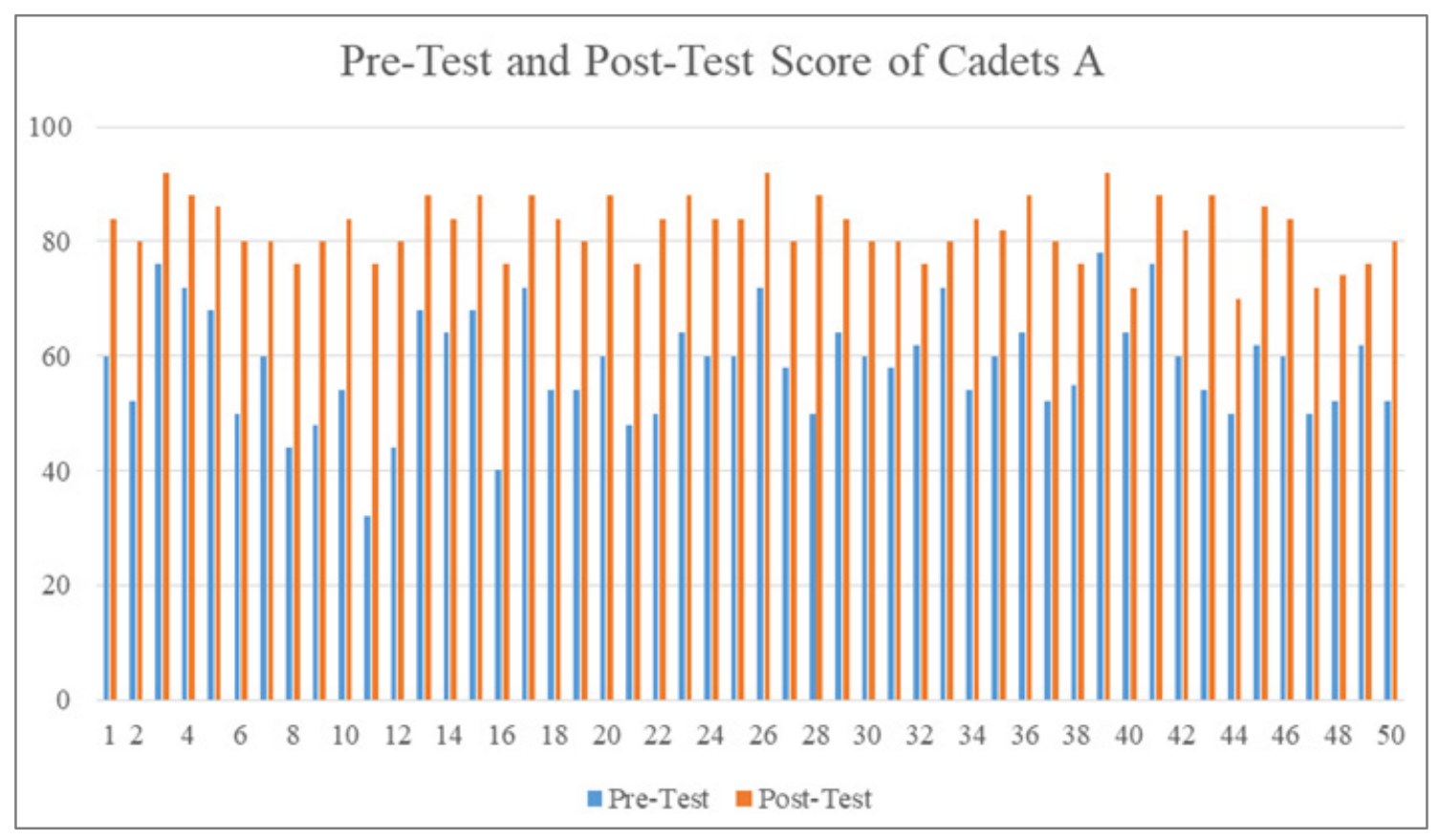

Figure 3. Pre-test and Post-test score of cadets A

Table 4. Comparison between high and low motivation

\begin{tabular}{|c|c|c|c|c|}
\hline & $\begin{array}{c}\text { Average } \\
\text { Score }\end{array}$ & $\begin{array}{c}\text { Minimum } \\
\text { Score }\end{array}$ & $\begin{array}{c}\text { Maximum } \\
\text { Score }\end{array}$ & Modus \\
\hline High & 79.00 & 70.00 & 90.00 & 75.00 \\
\hline Low & 72.38 & 57.50 & 87.50 & 62.50 \\
\hline
\end{tabular}

Table 4 describes the comparison between high and low motivation capabilities with achievement subjects. Students with high motivation at post-test get an average motivation score of 79 with a range of scores is 70-90. While students with low motivation at post-test get an average motivation score of 72.38 with a range of scores of 57.50 to 87.50 [36]. Thus, students with high motivation can have better learning outcomes than students with low learning motivation. In addition, the maximum score for students with low motivation is 87.50 , which shows that without EDA, students can get a score of more than 80 learning outcomes. These values show that the motivation of cadets is higher in terms of learning achievement than the cadets who had low motivation in the digital technique subject.

\subsection{Discussion}

The results explain that the guided inquiry model can provide innovations and address the problems at the university, especially the lack of understanding of the basic EDA procedures and concepts in subjects. The model can also find solutions to the problems faced by cadets. The learning outcomes of cadets taught through the experimental method with EDA are higher than the outcomes of cadets who learned through experimental methods with electronic components. Research on EDA has a rich history of solving difficult problems with the aim of developing effective algorithms in practice [37]. Its application in guided inquiry learning can show the effectiveness of the use of EDA in guided inquiry learning. The results of the data from the Digital Aviation Polytechnic Surabaya Aeronautical Engineering Program show that the motivation of cadets before the application of the model is still low but has increased significantly in after implementation [9].

The EDA toolkit for platform design is similar to the current set of manual tools. However, there is additional functionality to deal with the effects of increasing scale and complexity [13]. The intellectual challenge to solve this problem remains the same, but the extraction or checking of design rules is only needed for platform design, not for programming that platform. With the user base narrowed but the use of more intensive tools, the use of EDA for platform design tends to change. The development of EDA was formed to give effect to students' knowledge in solving complex electronic manual circuit problems [13], [38].

A formal methodology for verification and synthesis has been formulated to integrate inductive inference (learning) from examples with traditional deductive reasoning using hypotheses about the system structure [39]. It generalizes several effective approaches developed in the field of EDA, such as perfecting abstractions to help cadets to associate mathematics with the values of everyday life. This new theoretical framework formalizes some of the main connections between verification and synthesis, including the concept of verification by 
reducing it to synthesis, and therefore provides a general methodology for dealing with both problem domains.

This research has many applications in EDA, especially in synthesis and verification. Although it has been studied in many fields of computer science, such as artificial intelligence, the EDA community has contributed to the algorithm that has made the biggest impact [13]. This EDA approach addresses several key challenges in associating mathematics with the values of everyday life, such as environmental modeling, incomplete specifications, and the complexity of the underlying decision problems [12], [40]. Therefore, using EDA in guided inquiry learning using electronic components shows differences in learning outcomes for the digital technique subject.

\section{Conclusions}

The results and discussion of the research showed that the experiments using EDA and guided inquiry model influence the learning outcomes and motivation of cadets in the Air Digital Engineering Program. The researchers conclude that the results of this study is effective and beneficial to practitioners and educators in improving the learning outcomes and motivation of cadets through the implementation of the EDA and guided inquiry model in engineering education.

\section{Acknowledgments}

This research was supported by the Politeknik Penerbangan Surabaya. We thank all the facilitators and those who provided insights and expertise, which were very helpful in the completion of this research.

\section{REFERENCES}

[1] K. D. Nurhapsari, S. Hariyadi, and W. Suryono, "Prototipe Sistem Cadet Smart Tracking and Controlling Berbasis Web Server di Politeknik Penerbangan Surabaya," in Prosiding SNITP (Seminar Nasional Inovasi Teknologi Penerbangan), 2019, vol. 3, no. 1 .

[2] M. Rifai, "Studi Rancang Bangun Antenna J-Pole pada Komunikasi Aerodrome Surface," J. Penelit., vol. 3, no. 4, pp. 296-302, 2018.

[3] S. Lestari, "Pengaruh Motivasi Belajar Taruna Dan Kompetensi Dosen Terhadap Prestasi Belajar Taruna di Politeknik Penerbangan Surabaya," J. Penelit., vol. 2, no. 3, pp. 212-222, 2017.

[4] S. Suhanto, S. Setiyo, K. Kustori, and P. Iswahyudi, "Rancang Bangun Remote Control Desk Dengan Human Machine Interface Infor U pada Laboratorium Airfield Lighting System (AFL) Simulator," in Prosiding SNITP
(Seminar Nasional Inovasi Teknologi Penerbangan), 2017, vol. 1.

[5] D. D. López, G. D. Tormo, F. G. Mármol, J. M. A. Calero, and G. M. Pérez, "Live digital, remember digital: State of the art and research challenges," Comput. Electr. Eng., vol. 40, no. 1, pp. 109-120, 2014.

[6] F. Thouvenin, P. Hettich, H. Burkert, and U. Gasser, Remembering and forgetting in the digital age, vol. 38. Springer, 2018.

[7] N. P. Regmi, "Inclusive education in Nepal from theory to practice.” 2019.

[8] L. Hamburger and H. Chu, "Making Slope a Less Slippery Concept for English Learners," Amplifying Curric. Des. Qual. Learn. Oppor. English Learn., p. 115, 2019.

[9] A. C. Jones, E. Scanlon, and G. Clough, "Mobile learning: Two case studies of supporting inquiry learning in informal and semiformal settings," Comput. Educ., vol. 61, no. 1, pp. 21-32, 2013

[10] M. F. Amir, N. Fediyanto, C. Chotimah, and H. E. Rudiyanto, "Developing 3Dmetric Media Prototype through a Hypothetical Learning Trajector to Train Students Spatial Skill," J. Adv. Res. Dyn. Control Syst., vol. 10, no. 02Special Issue, pp. 1537-1542, 2018.

[11] M. F. Amir, C. Chotimah, R. Afandi, H. E. Rudyanto, and I. Anshori, "Design Research Study: Investigation of Increasing Elementary Student's Spatial Ability Using 3Dmetric," J. Adv. Res. Dyn. Control Syst., vol. 10, no. 6, pp. 1707-1713, 2018.

[12] M. Birnbaum, Essential electronic design automation (EDA). Prentice Hall Professional, 2004.

[13] H. S. Chu, O. Kurniawan, W. Zhang, D. Li, and E. P. Li, "Integrated system-level electronic design automation (EDA) for designing plasmonic nanocircuits," IEEE Trans. Nanotechnol., vol. 11, no. 4, pp. 731-738, 2012.

[14] A. A. K. Nielsen et al., "Genetic circuit design automation," Science (80-. )., vol. 352, no. 6281, p. aac7341, 2016.

[15] Y. Fukumoto, S. Miura, H. Ikeda, T. Nakayama, S Tanimoto, and H. Uemura, "A method of automatic placement that reduces electromagnetic radiation noise from digital printed circuit boards," in IEEE International Symposium on Electromagnetic Compatibility. Symposium Record (Cat. No. 00CH37016), 2000, vol. 1, pp. 363-368.

[16] J. D. Zakis, "The art of electronic design using multiple media," in Proceedings IEEE 1st International Conference on Multi Media Engineering Education, 1994, pp. 437-442.

[17] C. Slivinsky, "Multimedia and Web Techniques for Teaching Circuits I," Age (Omaha)., vol. 4, p. 1, 2000.

[18] L. P. Rieber, "Multimedia learning in games, simulations, and microworlds," Cambridge Handb. Multimed. Learn., pp. 549-567, 2005.

[19] W. Setyawan, M. Rusijono, and M. Jannah, "T-Mobile Learning Android Model-Based to Improve Students' Listening Capability," in 1st International Conference on Education Innovation (ICEI 2017), 2018.

[20] B. B. Gillani, "Inquiry-Based Training Model and the Design of E-Learning Environments.," Issues Informing Sci. 
Inf. Technol., vol. 7, 2010.

[21] G. Y.-M. Kao, S. S. J. Lin, and C.-T. Sun, "Breaking concept boundaries to enhance creative potential: Using integrated concept maps for conceptual self-awareness," Comput. Educ., vol. 51, no. 4, pp. 1718-1728, 2008.

[22] M. Copeland, Socratic circles: Fostering critical and creative thinking in middle and high school. Stenhouse Publishers, 2005.

[23] C. Lin, C. Chiu, C. Hsu, T. Wang, and C. Chen, "The effects of computerized inquiry-stage-dependent argumentation assistance on elementary students' science process and argument construction skills," J. Comput. Assist. Learn., vol. 34, no. 3, pp. 279-292, 2018.

[24] H. Saputra, A. Suhandi, and A. Setiawan, "Profile of inquiry skills pre-service physics teacher in Aceh," in Journal of Physics: Conference Series, 2019, vol. 1157, no. 3, p. 32046.

[25] D. Rukmana, "Integration of Learning Cycle Stage with Inquiry Labs Method in Learning Physics to Improve Cognitive Ability and Science Process Skills of High School Student," Form. J. Ilm. Pendidik. MIPA, vol. 8, no. 2, 2018.

[26] T. Howell and T. James, "Innovative Instructional Design to Alleviate the Shortage of Clinical Practice Sites for Education Through the Use of a Simulated OB Experience," J. Obstet. Gynecol. Neonatal Nurs., vol. 41, 2012.

[27] J. Xu, D. Xu, and Y. Lu, "Resident participation in post-Lushan earthquake housing reconstruction: a multi-stage field research method-based inquiry," Environ. hazards, vol. 15, no. 2, pp. 128-147, 2016.

[28] J. Krauss and S. Boss, Thinking through project-based learning: Guiding deeper inquiry. Corwin Press, 2013.

[29] D. Llewellyn, Teaching high school science through inquiry: A case study approach. Corwin Press, 2005.

[30] C. C. Kuhlthau, L. K. Maniotes, and A. K. Caspari, Guided inquiry: Learning in the 21st century: Learning in the 21st century. Abc-Clio, 2015.

[31] G. Kaya and S. Yılmaz, "Açık sorgulamaya dayalı öğrenmenin öğrencilerin başarısına ve bilimsel süreç becerilerinin gelișimine etkisi," Hacettepe Üniversitesi Eğitim Fakültesi Derg., vol. 31, no. 2, pp. 300-318, 2016.

[32] M. M. Ferreira and A. R. Trudel, "The impact of problem-based learning (PBL) on student attitudes toward science, problem-solving skills, and sense of community in the classroom," J. Classr. Interact., pp. 23-30, 2012.

[33] W. Herry Setyawan et al., "The effect of an android-based application on T-Mobile learning model to improve students' listening competence," in Journal of Physics: Conference Series, 2019, vol. 1175, no. 1 .

[34] T. Nakanishi, K. Sugiyama, and M. Kitano, "Demonstration of negative group delays in a simple electronic circuit," Am. J. Phys., vol. 70, no. 11, pp. 1117-1121, 2002.

[35] C. Baker, "Quantitative research designs: Experimental, quasi-experimental, and descriptive." Jones and Bartlett Learning, 2017.

[36] S. Arikunto, Prosedur Penelitian. Jakarta: Rineka Cipta, 2012 .

[37] F. B. Heile and B. A. Fairbanks, "Work group computing for electronic design automation.” Google Patents, Nov-1999.

[38] J.-N. Zheng, C.-F. Chien, T.-Y. Lin, S.-W. Liu, and W.-T. Huang, "Electronic Design Automation (EDA) Scheduling System in IC Design Industry," in 2019 IEEE International Conference on Smart Manufacturing, Industrial \& Logistics Engineering (SMILE), 2019, pp. 221-225.

[39] S. A. Seshia, "Autonomic reactive systems via online learning," in Proceding 4th International Conforence on Autonomic Computing, 2007, pp. 162-171.

[40] R.-S. Tsay and C.-C. Chang, "Electronic design automation tool for the design of a semiconductor integrated circuit chip." Google Patents, Oct-1995. 